Acta vet. scand. $1970,11,594-599$.

From the Department of Food Hygiene, Veterinary College of Norway, Oslo, and the Norwegian Fur Farmers Organization, Research Division, Oslo, Norway.

\title{
SUSCEPTIBILITY OF MINK TO CLOSTRIDIUM BOTULINUM TYPE C TOXIN
}

\author{
By \\ M. Yndestad and G. Loftsgård
}

The tolerance of mink to Clostridium botulinum type $\mathrm{C}$ toxin has been discussed by several workers.

Quortrup \& Gorham (1949) reported that mink which received approximately 100,000 MLD type $\mathrm{C}$ toxin orally, died within $48 \mathrm{hrs}$., although, in this case further titration of the toxin was not performed.

Wagenaar et al. (1953) found that mink given 10,000 MLD type $\mathrm{C}$ toxin died, and 1 died out of 2 mink which each received 1,000 MLD. The same authors also showed that mink were relatively resistant to the botulinal toxins of the types A, B and E. Similar results concerning type E toxin were obtained by Skulberg \& Valland (1969).

In 1955 , Dinter \& Kull found that mink died when exposed to 4,000 MLD type $\mathrm{C}$ toxin orally, whereas mink which received 2,500 MLD survived. When administered intraperitoneally only 50 MLD were necessary to cause death. Tjaberg \& Skulberg (1968) demonstrated that mink kits of about $500 \mathrm{~g}$ succumbed after being exposed to 4,000 MLD type $C$ toxin orally, while toxin levels of 2,500 MLD or less gave no rise to symptoms of botulism. When injected subcutaneously, 100 MLD type C toxin were lethal to a mink kit weighing $500 \mathrm{~g}$.

The results above do not correspond well with the observations made during the large botulism outbreaks in Norway in 1967, which strongly indicated that the tolerance of mink to this type of toxin was extremely low (Gustavsen et al. 1969). A relatively low tolerance in mink compared with mice which are 
the most commonly used test animal could also be part of the difficulties experienced by many workers when trying to demonstrate the presence of low levels of toxin in feeds actually being the cause of outbreaks of botulism in mink.

The experiments reported in this paper were performed to obtain further information on the susceptibility of mink to type C toxin.

\section{MATERIALS AND METHODS}

The toxin was produced by a Clostridium botulinum type $\mathrm{C}$ Nerz strain as reported by Tjaberg \& Skulberg (1968) and kindly placed at our disposal by dr. Skulberg.

From a stock solution carefully titrated in mice of $20 \mathrm{~g}$ a series of dilutions were made and immediately frozen in glass vials. The standardized toxin dilutions were stored at $-25^{\circ} \mathrm{C}$ and each vial was thawed immediately before use. Control titrations in mice of toxin stored in this way were performed during the course of the experiments. No changes in toxicity were observed. The toxin activity is expressed in MLD meaning the minimum dose which injected intraperitoneally kills all 4 out of 4 mice injected with the same amount of toxin.

Mink, approximately 7 months old and of different sex and type, were used as test animals. Weights ranged from 700 to $1,200 \mathrm{~g}$. Two older males, weighing $1,250 \mathrm{~g}$ and $1,500 \mathrm{~g}$ were also included. The mink were divided into 2 groups, 1 receiving the toxin mixed into a reduced portion of the diet to secure a complete intake, and the other group by administration subcutaneously in the axillary region.

\section{RESULTS}

The results obtained from the susceptibility tests in mink are shown in Tables 1 and 2. Mink which developed symptoms of botulism were observed until they either recovered or died.

Oral administration of toxin. From Table 1 is seen that all animals which received 360 MLD toxin or more in their feed, died (nos. 1-6). Out of 10 mink given 180 MLD, 2 died (nos. 11, 13), 4 developed mild symptoms of botulism such as reduced appetite, apathy and moderate incoordination (nos. 7, 8, 10, 14), while the remaining 4 showed no clinical symptoms at all. On the 90 MLD level, only 1 of 6 mink was moderately affected (no. 20 ), the others remaining apparently normal. 
T a ble 1. Experiments in mink with peroral administration of Clostridium botulinum toxin type $\mathrm{C}$.

\begin{tabular}{|c|c|c|c|c|c|c|c|c|c|}
\hline \multirow{2}{*}{$\begin{array}{l}\text { Mink } \\
\text { no. }\end{array}$} & \multirow{2}{*}{$\begin{array}{l}\text { Weight } \\
\text { in } \mathrm{g}\end{array}$} & \multirow[b]{2}{*}{ MLD } & \multicolumn{7}{|c|}{ Symptoms } \\
\hline & & & $12 \mathrm{hrs}$. & 1. day & 2. day & 3. day & 4. day & 5. day & $\begin{array}{l}\text { 6. day } \\
\text { or more }\end{array}$ \\
\hline 1 & 930 & 5760 & ++ & D & & & & & \\
\hline 2 & 800 & 2880 & ++ & D & & & & & \\
\hline 3 & 980 & 1440 & ++ & D & & & & & \\
\hline 4 & 980 & 720 & - & ++ & D & & & & \\
\hline $\mathbf{5}$ & 900 & 360 & 一 & ++ & D & & & & \\
\hline 6 & 800 & 360 & - & + & ++ & D & & & \\
\hline 7 & 1200 & 180 & - & - & + & + & + & + & $\mathbf{R}$ \\
\hline 8 & 700 & 180 & - & - & + & + & + & + & $\mathbf{R}$ \\
\hline 9 & 900 & 180 & - & - & - & - & - & - & - \\
\hline 10 & 950 & 180 & - & - & - & + & + & + & $\mathbf{R}$ \\
\hline 11 & 800 & 180 & 一 & + & ++ & ++ & D & & \\
\hline 12 & 1000 & 180 & - & - & - & - & - & - & - \\
\hline 13 & 800 & 180 & - & + & ++ & ++ & D & & \\
\hline 14 & 700 & 180 & - & - & + & + & + & $\mathbf{R}$ & \\
\hline 15 & 1000 & 180 & - & - & - & - & - & - & - \\
\hline 16 & 1500 & 180 & - & - & - & - & - & - & - \\
\hline 17 & 950 & 90 & - & - & - & - & - & - & - \\
\hline 18 & 950 & 90 & - & - & - & - & - & - & - \\
\hline 19 & 1000 & 90 & - & - & - & - & - & - & - \\
\hline 20 & 800 & 90 & $\cdot-$ & - & - & - & + & + & $\mathbf{R}$ \\
\hline 21 & 1200 & 90 & - & - & - & - & - & - & - \\
\hline 22 & 1250 & 90 & - & - & - & - & - & - & - \\
\hline
\end{tabular}

Explanation of symbols:

MLD $=$ Mouse lethal doses.

- $\quad=$ No symptoms of disease.

$+\quad=$ Vague symptoms of botulism.

$++=$ Typical symptoms of botulism.

$\mathrm{D}=$ Dead.

$\mathrm{R} \quad=$ Complete recovery.

Subcutaneous administration of toxin. From Table 2 is seen that mink died after being exposed to 36 MLD toxin or more (nos. 1-4). Eighteen MLD toxin proved fatal for 2 out of $3 \mathrm{mink}$ (nos. 6-7), while the third recovered after being severely ill with paresis and dyspnea. All the animals which received 9 MLD showed more or less typical signs of botulism with anorrhexia and ataxia, but none died (nos. 8-11).

Of the animals given 4.5 or 2.25 MLD (nos. 12-17) only 1 mink exhibited vague symptoms of disease. 
T a b le 2. Experiments in mink with subcutaneous injections of Clostridium botulinum toxin type $\mathrm{C}$.

\begin{tabular}{|c|c|c|c|c|c|c|c|c|c|}
\hline \multirow{2}{*}{$\begin{array}{l}\text { Mink } \\
\text { no. }\end{array}$} & \multirow{2}{*}{$\begin{array}{l}\text { Weight } \\
\text { in } \mathrm{g}\end{array}$} & \multirow[b]{2}{*}{ MLD } & \multicolumn{7}{|c|}{ Sy mptoms } \\
\hline & & & $12 \mathrm{hrs}$. & 1. day & 2. day & 3. day & 4. day & 5. day & $\begin{array}{l}\text { 6. day } \\
\text { or more }\end{array}$ \\
\hline 1 & 810 & 72 & ++ & ++ & D & & & & \\
\hline 2 & 1010 & 36 & ++ & ++ & D & & & & \\
\hline 3 & 980 & 36 & - & ++ & ++ & D & & & \\
\hline 4 & 740 & 36 & ++ & ++ & ++ & D & & & \\
\hline 5 & 950 & 18 & - & + & ++ & ++ & ++ & ++ & $\mathbf{R}$ \\
\hline 6 & 1020 & 18 & - & + & ++ & ++ & ++ & D & \\
\hline 7 & 860 & 18 & - & $+t$ & D & & & & \\
\hline 8 & 910 & 9 & - & + & + & ++ & + & + & $\mathbf{R}$ \\
\hline 9 & 850 & 9 & - & - & + & + & $\mathbf{R}$ & & \\
\hline 10 & 820 & 9 & - & - & + & ++ & ++ & + & $\mathbf{R}$ \\
\hline 11 & 800 & 9 & - & - & $\dot{t}$ & + & + & $\mathbf{R}$ & \\
\hline 12 & 1100 & 4.5 & - & - & - & - & - & - & - \\
\hline 13 & 700 & 4.5 & - & 一 & - & - & + & + & $\mathbf{R}$ \\
\hline 14 & 970 & 4.5 & - & - & - & - & - & - & - \\
\hline 15 & 840 & 4.5 & - & - & - & - & - & - & - \\
\hline 16 & 1000 & 2.25 & - & - & - & - & - & - & - \\
\hline 17 & 920 & 2.25 & - & -- & - & - & - & - & - \\
\hline
\end{tabular}

For explanation of symbols see Table 1.

\section{DISCUSSION}

The recorded experiments indicate that adult mink, weighing approximately $900 \mathrm{~g}$, will die when given 360 MLD or more of botulinum type $\mathrm{C}$ toxin orally. After subcutaneous injection the majority of animals died after doses of 18 MLD. These results indicate that the toxin is $\mathbf{1 0}$ to 20 times more potent for mink when it is administered subcutaneously than after being given in the feed.

On the basis of these results is calculated that, per $\mathrm{g}$ test animal, 0,04 MLD (0.02-0.04) will kill a mink (subcutaneously), whereas $0.05 \mathrm{MLD}$ is deadly for mice of $20 \mathrm{~g}$ (intraperitoneally). These observations indicate that there is some difference between mice and mink as to the susceptibility per gram of body weight after parenteral application of the toxin.

The discrepancies between tolerance levels for mink reported previously and the lower values demonstrated in these experi- 
ments may partly depend on differences in the potency of the toxins produced by different strains. More likely the testing procedure could be responsible. The standardization of the toxin dilution and handling techniques applied in these experiments probably have reduced the possibilities that changes in the potency of the toxin during the experiments might occur.

Our experiences from practical examinations of suspected feed containing very low quantities of type C toxin (1 MLD per g or less) indicate that mink are the test animals of choice. This is only partly due to the fact that mink are more susceptible to type $\mathrm{C}$ toxin than mice. The most decisive factor, in our opinion, is that larger amounts of suspected material may be included in the toxin demonstration procedure. Two-hundred-and-fifty $\mathrm{g}$ of feed is a normal daily ration for mink. In cases with low toxicity in the feed in question (1 MLD per g or less), demonstration of the toxin by means of the usual procedure involving injections of extracted toxin into mice may be difficult and will very often give unreliable results. By feeding mink with normal rations of test material containing about 1 MLD per g for several consecutive days the animals will receive approximately 250 MLD of toxin daily. This toxin intake may not produce immediate signs of disease, but continued feeding with the test material may often result in clinical symptoms of botulism. The reason may be accumulation of toxin in the tissues of the animal or stepwise increasing damages in the neuro muscular apparatus (Loftsgård et al., in press).

\section{ACKNOWLEDGMENT}

The authors wish to thank Director of research Arne Helgebostad at the State Experimental Farm for Fur Breeding Animals, Heggedal, for valuable advice and assistance and for providing mink for the experiments.

\section{REFERENCES}

Dinter, Z. \& K.-E. Kull: Über die Empfänglichkeit des Nerzes für die Botulinus-Toxine A und $\mathrm{C}$. (The susceptibility of mink to botulinus-toxins A and C). Nord. Vet.-Med. 1955, 7, 549-563.

Gustavsen, S., S. Hauge, G. Loftsgård, T. Oftebro, L. Rosseb $\emptyset$, T. B. Tjabjerg \& T. Aaneland: Repeated botulism outbreaks in mink caused by feed from a central processing plant. Canad. vet. J. $1969,10,244-247$. 
Loftsgård, G., M. Yndestad \& A. Helgebostad: Accumulated effect of repeated dosage of botulinal toxin type $\mathrm{C}$ in mice and mink. Canad. vet. J. In press.

Quortrup, E. R. \& J. R. Gorham: Susceptibility of furbearing animals to the toxins of Clostridium botulinum types A, B, C and E. Amer. J. vet. Res. 1949, 10, 268-271.

Skulberg, A. \& M. Valland: Susceptibility of mink to Clostridium botulinum type E toxin. Acta vet. scand. 1969, 10, 137-145.

Tjaberg, T. B. \& A. Skulberg: Minks mottagelighet for Clostridium botulinum type G toksin. (Susceptibility of mink to Clostridium botulinum type C toxin). Nord. Vet.-Med. 1968, 20, 313-318.

Wagenaar, R. O., G. M. Dack \& D. P. Mayer: Studies on mink food experimentally inoculated with toxin-free spores of Clostridium botulinum types A, B, C and E. Amer. J. vet. Res. 1953, 14, $479-483$.

\section{SUMMARY}

Investigations to determine the exact susceptibility of mink to Clostridium botulinum type $\mathrm{G}$ toxin clearly showed that mink were considerably less resistant to this toxin than has previously been described. Mink weighing approximately $900 \mathrm{~g}$ were killed by 360 MLD when toxin was mixed into the feed. By subcutaneous injection, the lethal dose was determined to be in the range of 18 to 36 MLD.

When comparing the susceptibility per $g$ of body weight after parenteral application of the toxin, mink proved to be less resistant than mice to this type of toxin. Continued feeding tests in mink with suspected material is pointed out as a preferable method for practical demonstrations of Clostridium botulinum type $\mathrm{C}$ toxin in cases where the toxin content in the suspected material is very low (1 MLD per $\mathrm{g}$ or less).

\section{SAMMENDRAG}

Minkens mottagelighet for Clostridium botulinum type C toksin.

Unders $\varnothing$ kelser for å klarlegge minkens mottagelighet for botulinumtoksin type $\mathrm{C}$ viste at mink var adskillig mer mottagelig for dette toksin enn hva som tidligere er angitt. Mink på ca. $900 \mathrm{~g}$ blev drept av 360 MLD når toksinet var blandet i fóret. Ved subcutan applikasjon lå letal-dosen i området 18-36 MLD.

En sammenligning mellom den subcutane letaldose på mink og den intraperitoneale letaldose på mus beregnet pr. g kroppsvekt viste at mink var mindre resistent enn mus overfor denne type toksin.

Det understrekes at man også av praktiske hensyn særlig ved påvisning av svært lave toksinmengder i mistenkt fór (1 MLD eller mindre) vil foretrekke mink som testdyr og da gi gjentatte orale doser av det suspekte materialet $\mathrm{i}$ den daglige fórrasjon. 